\title{
The impact of spatio-temporal changes in flora attributes and pollen availability on insect visitors in Lamiaceae species
}

\author{
Jacek Jachuła ${ }^{1}$, Małgorzata Wrzesień ${ }^{2}$, Monika Strzałkowska-Abramek ${ }^{1}$, Bożena Denisow ${ }^{1 *}$ \\ ${ }^{1}$ Department of Botany, Laboratory of Horticultural Plants Biology, University of Life Sciences in Lublin, 15 Akademicka \\ str., 20-950 Lublin, Poland \\ ${ }^{2}$ Department of Geobotany, Institute of Biology and Biochemistry Maria Curie-Skłodowska University, 19 Akademicka \\ str., 20-033 Lublin, Poland
}

\begin{abstract}
There is growing evidence that food, in particular pollen, limitation is the strongest factor in pollinator decline. We have considered the potential effects of diversity in plant-community attributes as well as variations in the pollen and energy amount on the abundance and frequency of insect visitors to the Lamiaceae species Salvia pratensis L., S. verticillata L., Thymus serpyllum L., Betonica officinalis L. syn. Stachys officinalis (L.) Trevis., and Origanum vulgare L. The species were grown in two different habitat types (dry grassland vs. railway embankment) in the Lublin Upland, Poland. We found significant inter-species, inter-habitat, and inter-year disparities in the pollen mass and total energy amount per unit area. Canonical correspondence analysis (CCA) revealed that the blossom cover, species richness, and diversity noted at the plant community level significantly influenced the distribution of insect visitors to Lamiaceae species. The pollen caloric value and pollen abundance (but not the protein content in the pollen) had a considerable impact on the abundance and frequency of honeybees, bumblebees, and solitary bees in Lamiaceae flowers. Butterflies, beetles and flies did not respond to these factors. The model including all variables explained $66.4 \%$ of the observed variance. The studied Lamiaceae species, due to abundant flowering and good pollen nutritional value should be considered in the protocols to improve food resources, especially for social bees; however, disparities in pollen quantity and energy amount should not be ignored.
\end{abstract}

Keywords: dry grasslands, pollen caloric value, pollen mass, pollinators, railway embankments

\section{Introduction}

Human activities are having an impact on ecosystems globally to an unprecedented degree (Hoekstra et al. 2005) and species differ tremendously in their responses to environmental changes. In particular, pollinators are undergoing severe population declines following multi-directional environmental transformations and destruction of pollinator-friendly habitats (Hülsmann et al. 2015). The role of pollinator service in general biodiversity conservation (Lonsdorf et al. 2009), functioning of biocenoses and ecosystems (Kunin 1997, Steffan-Dewenter 2003, Lázaro et al. 2009), development of the agricultural sector (Klein et al. 2007), and indirectly in human health is unquestionable (Gallai et al. 2009). Therefore, the pollinator decline phenomenon has been described as a 'pollination crisis' and has attracted attention globally from science, business, and even politicians
(Ghazoul 2005). The 'pollination crisis' is evident in declines and damage to webs of plant-pollinator interaction (Lázaro et al. 2013). These declines are usually attributed to multiple interacting causes, rather than one single cause (Vanbergen 2013). It has been suggested that nesting, breeding, and food niches as well as the accessibility of refugia for the avoidance of chemical exposure regulate the size of pollinator populations (Roulston and Goodell 2011). However, there is growing evidence that food limitation (decreased dietary diversity and reduced food abundance) is the strongest factor in pollinator decline (Garibaldi et al. 2013, González-Varo et al. 2013, Ollerton et al. 2014, Vaudo et al. 2015). As pollinator nutrition entirely relies on the nectar and pollen available in flowers, the main conservation issue is to develop and implement tools aimed at improving flower-rich habitats (Dicks et al. 2015). One of the concepts is the protec-

* Corresponding author, e-mail: bozena.denisow@up.lublin.pl 
tion of existing natural habitats identified as drivers of pollinator biodiversity (Albrecht et al. 2007). Recently, there has been increasing interest in proper management of alternative (man-made) habitats (Lowenstein et al. 2015). This concept has arisen from the current expansion of both urban and open man-made habitats and the growing body of evidence showing that these habitats fulfil a significant role in supporting a high level of pollinator diversity and population size (Banaszak-Cibicka and Żmihorski 2012, Moroń et al. 2014). However, the provided data indicate that pollinator taxa respond differently to the natural-to-urban gradient and to the surrounding land use, i.e. rural-agricultural sites are friendlier to hoverfly species, while urban sites support wild bees (e.g. Verboven et al. 2014). Numerous methods can be applied to estimate habitat quality, from the level of individual species (flowers) through patches to biotopes and landscape (Szigeti et al. 2016).

In Europe, semi-natural dry grasslands (steppe-like 'warm-stage refugia') are among the most species-rich plant communities. These sites create refuges for rare and endangered plants and invertebrates (WallisDeVries et al. 2002), as well as for a variety of nectariferous and polleniferous plants (Wrzesień and Denisow 2006) in a modern rural landscape. There is evidence that the value of man-made habitats for pollinators varies considerably, e.g. the level of diversity and abundance of spontaneous bee forage flora is higher in railway embankments along low- than along high-traffic volume tracks (Wrzesień et al. 2016).

Pollen is considered to be an important resource (Müller et al. 2006), as it is a main source of protein, vitamins, mineral salts, organic acids, and hormones (Pacini 2000, Szczęsna 2006). It is obvious that inadequate pollen resources usually lead to disorders in physiological processes at different stages of insect life cycles and are particularly detrimental for developing larvae and young bees (Alaux et al. 2010, Nicolson 2011). In the case of Apis mellifera, protein deficiencies have an indirect effect on the income of apiaries and reduce honey yields (Keller et al. 2005). It has been proposed that the restoration and management of pollinator-friendly habitats should begin with an inventory of the resources provided by particular species and alternative habitats (e.g. Fussell and Corbet 1992, Denisow 2009, Garbuzov and Ratnieks 2014, Denisow and Wrzesień 2015b). Lamiaceae species are important components of plant communities in Europe (Petanidou and Vokou 1990, Petanidou and Smets 1995). In Poland, Lamiaceae species are frequently found in xerothermic swards and on ruderal sites, e.g. along railway embankments (Wrzesień and Denisow 2006a, b). They form dense patches and flower abundantly and by that means potentially could support floral resource for pollinators (e.g. Bożek 2003b).

In this study, we evaluated how the composition, abundance, and richness of the flora as well as the flowering spectrum at the community level can influence the abundance and frequency of insect visitors to several Lamiaceae species. Within the study area, five Lamiaceae species (Salvia pratensis L., S. verticillata L., Thymus serpyllum L., Betonica officinalis L. syn. Stachys officinalis (L.) Trevis., and Origanum vulgare L.) have been found to occur both in dry grasslands and in plant communities developed on railway embankments, therefore we tried to assess how the potential quantity and quality of pollen resources of the same species can vary among habitat types (dry grassland vs. railway embankment). We also assessed the importance of the pollen mass, pollen energy available, and protein content in Lamiaceae pollen for bees and other insects by investigation of the spectrum of insect visitors.

\section{Materials and methods}

\section{Study sites}

In situ observations were performed in 2013-2014. The study area was located on the Lublin Upland, south-east-

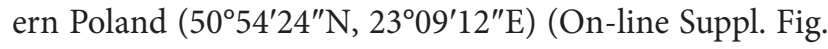
1). The floristic inventory of nectar- and/or pollen-yielding flora (hereinafter called forage flora) was made in (1) Festu-
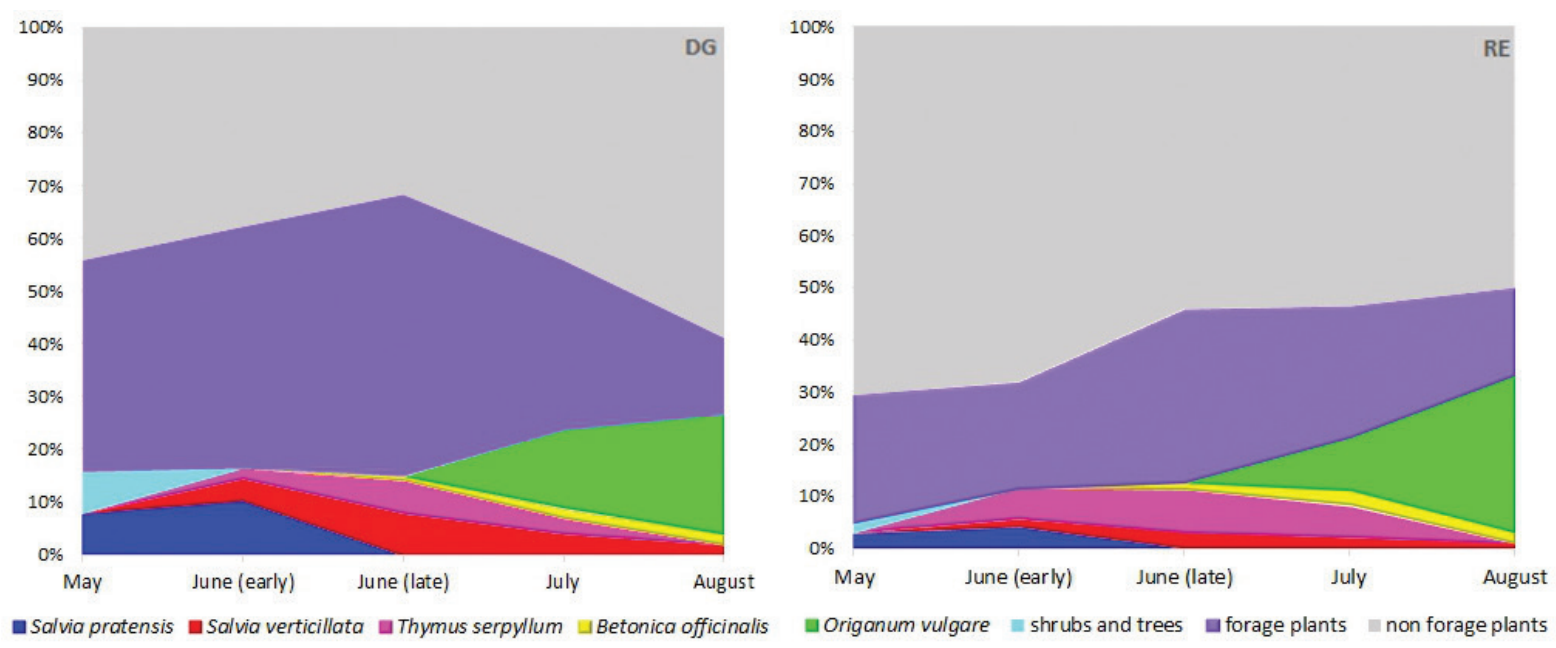

Fig. 1. Changes in seasonal pattern of flowering of forage and non-forage plants in the dry grassland (DG) and the railway embankment (RE) habitats in SE Poland. The percentage of plant species in bloom at each study point was established based on the cover of plant species in particular transects ( $\mathrm{n}=5$ per habitat). Mean from 2013-2014. 
co-Brometea Br.-Bl. \& Tüxen ex Soó 1947 dry grassland and (2) man-made habitat along the railway embankment (line No. 69 Rejowiec-Hrebenne), situated near the grassland area. The dry grassland occupies the edge of the river valley and is located on the SE slope (195 $\mathrm{m}$ a.s.l., inclination $50^{\circ}$ ). Since 2008, the Festuco-Brometea site has been included in the Natura 2000 network of nature protection areas in the territory of the European Union. The railway embankment includes SE and SW slopes (200 $\mathrm{m}$ a.s.l., inclination $\left.42^{\circ}\right)$. The vegetation is composed of diverse flowering plant species, i.e. natural, ruderal, and segetal.

A temperate climate with oceanic and continental influences is characteristic for the Lublin Upland (annual temperature averaged $7.4^{\circ} \mathrm{C}$, annual precipitation averaged 630 $\mathrm{mm}$ ) (Kaszewski 2008).

\section{Vegetation survey}

The method of phytosociological relevés was employed to characterize the flora in the dry grassland and railway embankment habitats. The frequency and abundance of each vascular plant species was recorded according to BraunBlanquet (1964). Each experimental patch was randomly selected and was $200 \times 5-6 \mathrm{~m}$ in the dry grassland $(\mathrm{n}=5)$ and $300 \times 2 \mathrm{~m}$ in the railway embankment $(\mathrm{n}=5)$. The total coverage for each species was estimated visually and recorded using a cover-abundance scale within seven cover classes, i.e.: 1 to 5 individuals; + : a few individuals $(<20)$ with cover $<5 \%$; 1 : many individuals $(20-100)$ with cover < 5\%; 2: 5\%-25\% cover; 3: 25\%-50\% cover; 4: 50\%-75\% cover; 5: 75\%-100\% cover (van der Maarel 1979). This survey allowed us to analyse the flora composition, richness, and abundance in each habitat type. The geographic position of each experimental plot was recorded with a differential GPS. The plant nomenclature followed Mirek et al. (2002).

\section{Flowering phenology}

To establish the seasonal spectrum of forage species and non-forage species in bloom for every vegetation type, forage species have been defined according to literature data and own observations (Wrzesień and Denisow 2006a,b, Denisow and Wrzesień 2007). The experimental patches were monitored 5 times per year, i.e. in spring (2-10 May), early summer (5-10 June), summer (20-30 June and 15-30 July), and late summer (15-25 August). To assess flowering phenology, we followed the instruction of Denisow (2011). The coverage of the species in bloom was estimated with a coverabundance scale (in \%) as a percentage of the total area. For each time point, the species in bloom have been counted. The date of the onset of flowering and the duration of the flowering phase were documented for each species. The species full bloom was recorded as the period when $>75 \%$ of flowers in the population were in bloom (point 5 in the coverabundance scale). We also estimated the cover of non-forage plants. Species with low cover $(<5 \%)$ or singly noted have been excluded from the graphs and only the main flowering species are presented. The estimates were made on the base of 5 transect per each habitat.

\section{Pollen production, energy amount and protein content in pollen}

Due to the time-consuming character of the analyses, only five species (representatives from the Lamiaceae family) were selected for the study of pollen production. The observations were made and samples collected in two habitats (dry grassland and railway embankment) for each species. The following species: Salvia pratensis L., S. verticillata L., Thymus serpyllum L., Betonica officinalis L. syn. Stachys officinalis (L.) Trevis., and Origanum vulgare L. were chosen for the experiment.

Pollen production was assessed using the ether-ethanol method described in detail by Denisow (2011). During each year, we randomly selected well-developed flower buds $(\mathrm{n}=30-70)$ at the full flowering phase of each species. Buds were collected from different individuals $(n=10-15)$, placed in plastic containers, and transported to the laboratory in a portable cooler. In the laboratory, the anthers before dehiscence were dissected from the flower buds and placed in tarred vessels $(n=100-200$ anthers per sample; i.e. $25-50$ flowers). We collected 4 samples per species and habitat (in total $\mathrm{n}=40$ samples per year). The samples were transferred into a dryer (ELCON CL 65) at ca $33^{\circ} \mathrm{C}$ for approx. 20-30 days. Pure ether $(2-3 \mathrm{ml})$ was used to rinse pollen from the anthers. Next, 70\% ethanol (3-4 mL) was used to separate pollen from the anther tissues. Pollen production was expressed per flower and per $1 \mathrm{~m}^{2}$ for each species and habitat type. The pollen amount per unit area was determined using the detailed data of the flowering abundance established for every Lamiaceae species. We counted the number of flowers produced per unit area; all buds, flowers, and set fruits were counted in randomly chosen stems $(n=14-20)$. Next, the number of stems was determined using the circular frame (36.7 $\mathrm{cm}$ in diameter); $\mathrm{n}=15-20$ counts for each study site were made. The data was converted to the number of flowers per $1 \mathrm{~m}^{2}$.

The pollen energy amount (= pollen caloric value) was calculated using a value of $5.69 \mathrm{kcal} \mathrm{g}^{-1}$ (Petanidou and Vokou 1990) and was expressed in kcal per $1 \mathrm{~m}^{2}$.

The tests for the $\mathrm{N}$ content in pollen were performed according to the Kjeldahl method in 2013 for each species and habitat. The crude protein content was calculated by multiplying 5.60 by \% $\mathrm{N}$ in $100 \mathrm{~g}$ of pollen (Rabie et al. 1983).

\section{Insect visitors}

To assess the structure of insect visitor groups for each Lamiaceae species, we monitored the patches simultaneously in the two different habitats (dry grassland vs. railway embankment). The insect monitoring was made in the same patches where floristic surveys had been conducted. The observations were made in 7-15-day intervals during the fullbloom phase of each species. In each habitat, we randomly chose $1.0 \mathrm{~m}^{2}$ patches $(\mathrm{n}=3)$ and recorded the insect visitors that collected nectar and/or pollen from flowers of the studied Lamiaceae plants. Insect visitor activity was monitored between 9.00-17.00 h (GMT + 2 h). Earlier and later obser- 
vation hours have been excluded, as according to literature, the peak insects activity to Lamiaceae species are morning/ mid-day hours (Bożek 2000, 2003 a,b, 2008). Records (5-10min. per census) were made at each plot at two-(three)-hour intervals. The observations were made when weather conditions were favourable for the activity of insect visitors, i.e. the daily temperature was $23-28^{\circ} \mathrm{C}$, with low wind speed, and without rainfall. All flower-visiting insects were recorded and grouped into their taxonomic categories: honeybees $=$ Apis mellifera , bumblebees = Bombus spp., solitary bees $=$ Hymenoptera, flies $=$ Diptera, beetles $=$ Coleoptera . The procedure facilitated the apportionment of the proportion of insect categories to particular species as well as visitation frequency.

\section{Data analysis}

We used a variety of approaches to analyse the data. The vegetation within the dry grassland and the railway embankment was described by the species richness, Shannon diversity index ( $\left.\mathrm{H}^{\prime}\right)$, and evenness index (Pielou's J' evenness). The value of $\mathrm{H}^{\prime}$ ranges from 0 to 1 , with higher values representing more even distributions in abundance among species. J' is constrained between 0 and 1 . The lesser the variation in communities among the species, the higher the $J^{\prime}$ index is. The Mann-Whitney non-parametric test was used to compare the values of indices obtained for the dry grassland and the railway embankment (Stanisz 2007). The multivariate statistical package (MVSP) was used for these analyses (Kovach 2005).

To identify the general pattern of variation in the species composition within the entire data set of flora, an indirect ordination method (detrended correspondence analysis, DCA) was used (a unimodal response model; environmental gradient > 3) (Canoco 5.0, ter Braak and Šmilauer 2012). Subsequently, canonical correspondence analysis (CCA) was used to visualize and establish the relationship between the floristic composition of the vegetation plots (relevés) and the spatial distribution of insect visitors and between the insect visitor pattern and Lamiaceae species traits. For each type of vegetation, the data from the study periods were pooled. Seven environmental variables were analysed. Two groups of variables (1) Flora attributes, i.e. species richness (Richness), species diversity (Diversity), 'blossom cover' i.e. flow- er abundance (Cover), flowering season, (Flowering), and (2) Lamiaceae species traits, i.e. pollen amount (Pollen A), energy content in pollen (= pollen caloric value; Pollen E), and protein content in pollen (Pollen $\mathrm{P}$ ) were tested.

Analysis of variance (ANOVA) was applied to assess the difference in the mean values of the analysed traits among the populations and within the populations among the habitats and the years of the study. The normality of the data was evaluated prior to the analysis. If significant differences were detected, Tukey's HSD test was applied. Pearson's correlation (r) was established between the total pollen output and the studied criteria (abundance of blooming and mass of pollen in flowers). The level of statistical significance to measure the differences between the means for all the analyses was at $\mathrm{P}=0.05$. Statistical tests were performed with STATISTICA (StatSoft, Inc., Krakow), version 10.0.

\section{Results}

\section{Nectar and pollen yielding plants}

The total number of plant species found was 185 , of which 151 species $(81.6 \%)$ were identified as visited by insects (On-line Suppl. Tab. 1). In the dry grassland, 135 (112 forage species $=82.9 \%$ ) were documented, while 115 species (90 forage species $=78.2 \%$ ) were noted on the railway embankment. The species richness, species diversity, and species evenness was significantly higher on the dry grassland (U-test, Tab. 1). The number of forage species per relevé ranged from 10 to 48 (mean $=39.7 \pm 5.2$ in the grassland; mean $=19.9 \pm 5.8$ in the railway embankment). Species yielding both nectar and pollen predominated (138 species $=91.3 \%)$. Pollen as floral reward (= no nectar) was offered by 13 species $(8.6 \%)$ of the bee forage flora.

\section{Community-level changes in the flowering spectrum}

The pattern of the flowering of forage plants slightly differed between the dry grassland and the railway embankment sites (Fig. 1). In spring, more abundant flowering of forage plants was noted in the dry grassland. Here, the flowering peak was observed during the summer (June/July). In the summer period, the Lamiaceae species contributed substantially to the food availability for pollinators. On the railway embankment, the flowering of the forage plant species was shifted towards the end of the summer.

Tab. 1. Comparison of plant forage species richness (S), the values of diversity indices ( $\left.\mathrm{H}^{\prime}, \mathrm{J}\right)$, and the mean frequency of insect individuals to Lamiaceae flowers in the dry grassland and the railway embankment. Means \pm SD (standard deviation) are shown. The values indicated by the same small letter are not statistically different between the types of habitats (Mann-Whitney test has been applied; Z - statistic value, $\mathrm{P}$ - probability).

\begin{tabular}{|c|c|c|c|c|c|c|}
\hline & \multicolumn{4}{|c|}{ Type of habitat } & \multirow{3}{*}{$\mathrm{Z}$} & \multirow{3}{*}{$\mathrm{P}$} \\
\hline & \multicolumn{2}{|c|}{ dry grassland } & \multicolumn{2}{|c|}{ railway embankment } & & \\
\hline & mean & $\pm \mathrm{SD}$ & mean & $\pm \mathrm{SD}$ & & \\
\hline Species richness $(\mathrm{S})$ & $33.70^{\mathrm{b}}$ & 5.21 & $19.80^{\mathrm{a}}$ & 5.77 & 5.35 & 0.000 \\
\hline Diversity (H') & $1.50^{\mathrm{b}}$ & 0.08 & $1.24^{\mathrm{a}}$ & 0.12 & 5.48 & 0.000 \\
\hline Evenness (J’) & $0.984^{\mathrm{b}}$ & 0.011 & $0.974^{\mathrm{a}}$ & 0.013 & 2.52 & 0.013 \\
\hline Insects frequency per flower/per season & $0.005^{\mathrm{a}}$ & 0.002 & $0.022^{\mathrm{b}}$ & 0.01 & 4.16 & 0.004 \\
\hline
\end{tabular}




\section{Pollen production, energy content, and pollen protein}

Species, habitat, and year-to-year disparities were found for the mass of pollen produced in the flowers of Lamiaceae species (Tabs. 2, 3, 4). The lowest amount of pollen was found in the flowers of Thymus serpyllum and the highest in Betonica officinalis. For the same species, the mass of pollen produced per flower differed between the habitats. A significantly higher mass of pollen was produced in the flowers of Salvia pratensis $(\mathrm{df}=1, \mathrm{P}=0.033)$, S. verticillata $(\mathrm{df}=1, \mathrm{P}$ $=0.031)$, and Origanum vulgare $(\mathrm{df}=1, \mathrm{P}=0.028)$ growing in the dry grassland compared to those from plants in the railway habitat. In turn, T. serpyllum and B. officinalis produced similar pollen mass in the flowers of plants in both the dry grassland and the railway embankment $(\mathrm{df}=1, \mathrm{P}=$ 0.122 ; $\mathrm{df}=1, \mathrm{P}=0.242$, respectively). A higher amount of pollen per flower was produced in 2014: on average, 4-fold higher than in 2013.

A significant positive correlation was found between the pollen yield per $1 \mathrm{~m}^{2}$ and the mass of pollen per flower $(\mathrm{r}=$ $0.431, \mathrm{P}=0.033$ ) and between the pollen yield per $1 \mathrm{~m}^{2}$ and the number of flowers per $1 \mathrm{~m}^{2}(\mathrm{r}=0.844, \mathrm{P}=0.014)$. The number of Lamiaceae flowers per unit area was related to the species ( $\mathrm{df}=4, \mathrm{P}=0.035$ ) (Tab. 2). The lowest number of flowers, i.e. only 1.32 thousand per $1 \mathrm{~m}^{2}$, was noted in $S$. verticillata, while the highest number was recorded for $O$. vulgare - on average 201.61 thousand per $1 \mathrm{~m}^{2}$ (Tabs. 2, 3). The number of flowers developed per unit area was signifi- cantly higher in the dry grassland for four out of the five species studied. Only $O$. vulgare bloomed more abundantly on the railway embankment. For the same species, differences between study years were also established for the abundance of flowering (Tabs. 3, 4). On average, more flowers were produced in 2013.

The estimated total pollen production per $1 \mathrm{~m}^{2}$ and the total pollen energy available per $1 \mathrm{~m}^{2}$ differed among the species, between the populations developed in the dry vs. railway habitats (habitat effect), and among the years of the study (Tabs. 2, 3, 4). The lowest and the highest pollen yield and pollen energy amount were recorded for T. serpyllum $\left(\right.$ mean $=0.08 \mathrm{~g}$ per $1 \mathrm{~m}^{2}, 0.46 \mathrm{kcal}$ per $\left.\mathrm{m}^{2}\right)$ and $O$. vulgare $\left(\right.$ mean $=8.87$ g per $1 \mathrm{~m}^{2}, 44.83 \mathrm{kcal}$ per $\mathrm{m}^{2}$ ), respectively. On average, $S$. pratensis and $S$. verticillata produced similar pollen mass and energy amount per $1 \mathrm{~m}^{2}$. Comparing habitats, the total pollen yield and the energy amount were higher in the dry habitat than in the railway habitat. Only $O$. vulgare produced more pollen and energy amount (approx. $10 \%)$ on the railway plots, compared to the dry patches. The mean pollen mass and energy in $2013\left(2.09 \mathrm{~g}\right.$ per $1 \mathrm{~m}^{2}$, and $11.89 \mathrm{kcal}$ per $1 \mathrm{~m}^{2}$, average) was relatively low compared to that established for 2014-2.89 g per $1 \mathrm{~m}^{2}$ and $15.88 \mathrm{kcal}$ per $1 \mathrm{~m}^{2}$ (Tab. 3).

There were evident effects of the species $(\mathrm{df}=4, \mathrm{P}=$ $0.001)$ and habitat $(\mathrm{df}=1, \mathrm{P}=0.003)$ on the protein content in pollen (Tabs. 2, 4). The pollen of T. serpyllum, B. officinalis,

Tab. 2. The number of flowers per $1 \mathrm{~m}^{2}$, the mass of pollen produced, pollen energy available, protein content in pollen, and insect frequency in Lamiaceae species depending on habitat (DG - the dry grassland, and RE - the railway embankment). Means are calculated from 2013-2014. Standard deviations $( \pm S D)$ are given. ANOVAs were performed separately for each of analyzed feature. Means followed by the same small letter are not significantly different between habitats within species and that followed by the same capital letter are not different among species, according to Tukey HSD test.

\begin{tabular}{|c|c|c|c|c|c|c|c|c|c|c|c|c|c|}
\hline \multirow[t]{2}{*}{ Species } & \multirow[t]{2}{*}{ Site } & \multicolumn{2}{|c|}{$\begin{array}{c}\text { No. flowers } \\
\text { per } 1 \mathrm{~m}^{2} \text { (thousand) }\end{array}$} & \multicolumn{2}{|c|}{$\begin{array}{l}\text { Mass of pollen } \\
\text { per flower }(\mathrm{mg})\end{array}$} & \multicolumn{2}{|c|}{$\begin{array}{l}\text { Mass of pollen } \\
\text { per } 1 \mathrm{~m}^{2}(\mathrm{~g})\end{array}$} & \multicolumn{2}{|c|}{$\begin{array}{l}\text { Pollen energy per } \\
1 \mathrm{~m}^{2} \text { (kcal) }\end{array}$} & \multicolumn{2}{|c|}{ Protein (\%) } & \multicolumn{2}{|c|}{$\begin{array}{c}\text { Insect visitors } \\
\text { frequency per } \\
\text { flower/per season }\end{array}$} \\
\hline & & mean & $\pm \mathrm{SD}$ & mean & $\pm \mathrm{SD}$ & mean & $\pm \mathrm{SD}$ & mean & $\pm \mathrm{SD}$ & mean & $\pm \mathrm{SD}$ & mean & $\pm \mathrm{SD}$ \\
\hline \multirow{3}{*}{$\begin{array}{l}\text { Salvia } \\
\text { pratensis }\end{array}$} & DG & $7.11^{\mathrm{b}}$ & 2.33 & $0.02^{\mathrm{b}}$ & 0.01 & $0.14^{\mathrm{b}}$ & 0.04 & $0.81^{\mathrm{b}}$ & 0.16 & $28.8^{\mathrm{a}}$ & 5.1 & $0.003^{\mathrm{a}}$ & 0.0002 \\
\hline & $\mathrm{RE}$ & $3.42^{\mathrm{a}}$ & 1.21 & $0.01^{\mathrm{a}}$ & 0.00 & $0.03^{\mathrm{a}}$ & 0.00 & $0.19^{\mathrm{a}}$ & 0.01 & $26.0^{\mathrm{a}}$ & 2.6 & $0.013^{\mathrm{b}}$ & 0.0001 \\
\hline & Mean & $5.27^{\mathrm{B}}$ & & $0.02^{\mathrm{B}}$ & & $0.09^{\mathrm{A}}$ & & $0.50^{\mathrm{A}}$ & & $27.4^{\mathrm{B}}$ & & $0.008^{\mathrm{C}}$ & \\
\hline \multirow{3}{*}{ Salvia verticillata } & DG & $1.92^{\mathrm{b}}$ & 0.61 & $0.12^{\mathrm{b}}$ & 0.05 & $0.23^{\mathrm{b}}$ & 0.13 & $1.31^{\mathrm{a}}$ & 0.49 & $27.3^{\mathrm{a}}$ & 3.2 & $0.015^{\mathrm{a}}$ & 0.0024 \\
\hline & $\mathrm{RE}$ & $0.71^{\mathrm{a}}$ & 0.14 & $0.03^{\mathrm{a}}$ & 0.01 & $0.02^{\mathrm{a}}$ & 0.01 & $0.12^{\mathrm{b}}$ & 0.11 & $25.8^{\mathrm{a}}$ & 3.6 & $0.080_{\mathrm{b}}$ & 0.0035 \\
\hline & Mean & $1.32^{\mathrm{A}}$ & & $0.08^{\mathrm{CD}}$ & & $0.13^{\mathrm{A}}$ & & $0.72^{\mathrm{A}}$ & & $26.6^{\mathrm{B}}$ & & $0.047^{\mathrm{D}}$ & \\
\hline \multirow{3}{*}{$\begin{array}{l}\text { Thymus } \\
\text { serpyllum }\end{array}$} & DG & $12.83^{\mathrm{b}}$ & 5.08 & $0.01^{\mathrm{a}}$ & 0.00 & $0.13^{\mathrm{b}}$ & 0.02 & $0.73^{\mathrm{b}}$ & 0.19 & $22.7^{\mathrm{b}}$ & 2.1 & $0.006^{\mathrm{a}}$ & 0.0005 \\
\hline & $\mathrm{RE}$ & $7.30^{\mathrm{a}}$ & 2.04 & $0.01^{\mathrm{a}}$ & 0.00 & $0.07^{\mathrm{a}}$ & 0.01 & $0.42^{\mathrm{a}}$ & 0.07 & $17.6^{\mathrm{a}}$ & 1.5 & $0.011^{\mathrm{b}}$ & 0.0361 \\
\hline & Mean & $10.07^{\mathrm{C}}$ & & $0.01^{\mathrm{A}}$ & & $0.10^{\mathrm{A}}$ & & $0.57^{\mathrm{A}}$ & & $20.2^{\mathrm{A}}$ & & $0.009^{\mathrm{C}}$ & \\
\hline \multirow{3}{*}{$\begin{array}{l}\text { Betonica } \\
\text { officinalis }\end{array}$} & DG & $9.09^{\mathrm{b}}$ & 3.26 & $0.09^{\mathrm{a}}$ & 0.04 & $0.82^{\mathrm{b}}$ & 0.25 & $4.65^{\mathrm{b}}$ & 1.64 & $23.9^{\mathrm{b}}$ & 2.2 & $0.002^{\mathrm{a}}$ & 0.0011 \\
\hline & $\mathrm{RE}$ & $5.19^{\mathrm{a}}$ & 1.54 & $0.11^{\mathrm{a}}$ & 0.07 & $0.57^{\mathrm{a}}$ & 0.38 & $3.25^{\mathrm{a}}$ & 1.52 & $19.7^{\mathrm{a}}$ & 2.0 & $0.005^{\mathrm{b}}$ & 0.0023 \\
\hline & Mean & $7.14^{\mathrm{B}}$ & & $0.10^{\mathrm{D}}$ & & $0.69^{\mathrm{B}}$ & & $3.95^{\mathrm{B}}$ & & $21.8^{\mathrm{A}}$ & & $0.003^{\mathrm{B}}$ & \\
\hline \multirow{3}{*}{$\begin{array}{l}\text { Origanum } \\
\text { vulgare }\end{array}$} & DG & $122.00^{\mathrm{a}}$ & 7.02 & $0.06^{\mathrm{b}}$ & 0.03 & $7.32^{\mathrm{a}}$ & 4.81 & $41.65^{\mathrm{a}}$ & 19.18 & $28.7^{\mathrm{b}}$ & 2.5 & $0.001^{\mathrm{a}}$ & 0.0042 \\
\hline & $\mathrm{RE}$ & $281.22^{\mathrm{b}}$ & 107.78 & $0.03^{\mathrm{a}}$ & 0.02 & $8.44^{\mathrm{b}}$ & 5.32 & $48.00^{\mathrm{b}}$ & 30.21 & $18.8^{\mathrm{a}}$ & 2.5 & $0.001^{\mathrm{a}}$ & 0.0001 \\
\hline & Mean & $201.61^{\mathrm{D}}$ & & $0.05^{\mathrm{C}}$ & & $7.88^{\mathrm{C}}$ & & $44.83^{\mathrm{C}}$ & & $23.8^{\mathrm{C}}$ & & $0.001^{\mathrm{A}}$ & \\
\hline \multirow{2}{*}{ Mean for habitat } & DG & $30.59^{x}$ & 51.25 & $0.06^{\mathrm{Y}}$ & 0.05 & $1.63^{\mathrm{x}}$ & 3.14 & $9.83^{\mathrm{x}}$ & 17.86 & $26.3^{\mathrm{Y}}$ & 2.8 & 0.004 & 0.0056 \\
\hline & $\mathrm{RE}$ & $59.57^{\mathrm{Y}}$ & 123.93 & $0.04^{\mathrm{x}}$ & 0.04 & $1.83^{\mathrm{Y}}$ & 3.70 & $10.40^{\mathrm{Y}}$ & 21.06 & $21.6^{\mathrm{x}}$ & 4.0 & 0.022 & 0.0328 \\
\hline
\end{tabular}


Tab. 3. Year-to-year disparities in the number of flowers, mass of pollen, and pollen energy available (mean for Lamiaceae species studied and study sites). ANOVAs were performed separately for each of analyzed variable. Means followed by the same small letter are not significantly different between years, according to Tukey HSD test.

\begin{tabular}{lccccc}
\hline \multirow{2}{*}{ Variable } & \multicolumn{2}{c}{2013} & \multicolumn{2}{c}{2014} & $\begin{array}{c}\text { Mean } \\
\text { from years }\end{array}$ \\
\cline { 2 - 6 } & mean & $\pm \mathrm{SD}$ & mean & $\pm \mathrm{SD}$ & \\
\hline $\begin{array}{l}\text { No. flowers per } 1 \mathrm{~m}^{2} \\
\text { thous.) }\end{array}$ & $73.52_{\mathrm{b}}$ & 9.98 & $24.94 \mathrm{a}$ & 4.26 & 49.23 \\
$\begin{array}{l}\text { Mass of pollen per } \\
\text { flower (mg) }\end{array}$ & $0.03_{\mathrm{a}}$ & 0.01 & $0.12_{\mathrm{b}}$ & 0.02 & 0.07 \\
$\begin{array}{l}\text { Mass of pollen }\left(\mathrm{g} \mathrm{m}^{-2}\right) \\
\text { Pollen energy }\left(\mathrm{kcal} \mathrm{m}^{-2}\right)\end{array}$ & $2.09_{\mathrm{a}}$ & 0.36 & $2.89_{\mathrm{b}}$ & 0.86 & 2.49 \\
\hline
\end{tabular}

Tab. 4. ANOVA's of the effects of the species, the habitat, and the years of study on the studied variables in Lamiaceae species in south-eastern Poland.

\begin{tabular}{lccrc}
\hline Variable & Effect & df & \multicolumn{1}{c}{ F } & P - value \\
\hline \multirow{3}{*}{ Flowers per $1 \mathrm{~m}^{2}$ (number) } & species & 4 & 150.1 & 0.000 \\
& habitat & 1 & 62.2 & 0.001 \\
& year & 1 & 21.3 & 0.022 \\
\hline \multirow{3}{*}{ Dry weight of anthers $(\mathrm{mg})$} & species & 4 & 46.1 & 0.000 \\
& habitat & 1 & 4.6 & 0.038 \\
& year & 1 & 11.7 & 0.041 \\
\hline \multirow{2}{*}{ Mass of pollen per flower } & species & 4 & 40.2 & 0.000 \\
& habitat & 1 & 71.9 & 0.000 \\
& year & 1 & 0.4 & 0.020 \\
\hline \multirow{2}{*}{ Pollen energy $\left(\mathrm{kcal} \mathrm{m}^{-2}\right)$} & species & 4 & 24.5 & 0.015 \\
& habitat & 1 & 4.7 & 0.045 \\
& year & 1 & 17.2 & 0.026 \\
\hline \multirow{2}{*}{ Protein content in pollen (\%) } & species & 4 & 84.5 & 0.001 \\
& habitat & 1 & 205.2 & 0.003 \\
\hline
\end{tabular}

and $O$. vulgare accumulated more protein in the individuals located in the dry habitat. The protein content in the pollen of S. pratensis and S. verticillata was similar, irrespective of the habitat.

\section{Insect visitors}

The CCA model revealed that the blossom cover and the species richness noted in the study patches had a significant impact on the distribution of insect visitors to the Lamiaceae species (Fig. 2, Tab. 5). The pollen caloric value and pollen abundance also considerably influenced the structure of the insect visitors to the Lamiaceae flowers. The model including all variables explained $66.4 \%$ of the observed variance. The eigenvalues were 0.226 for axis 1 and 0.137 for axis 2 .

According to the CCA model, the abundance of pollinators to the Lamiaceae species was statistically significant, with

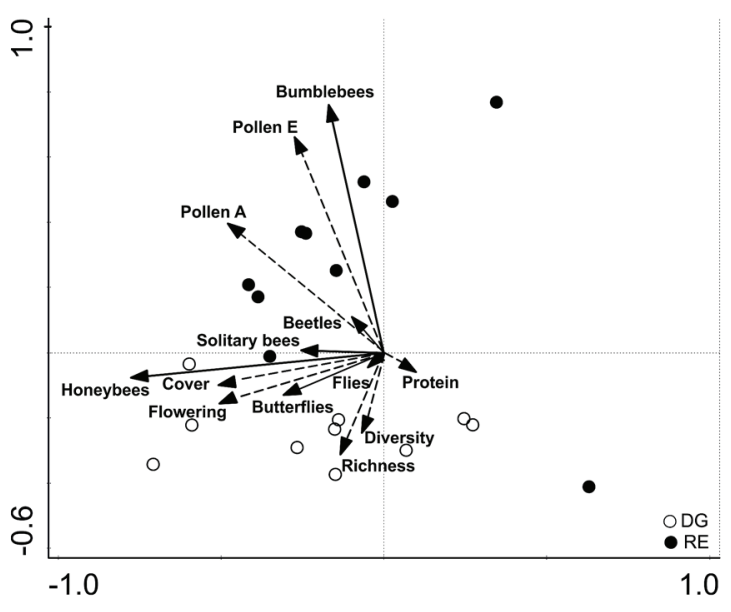

Fig. 2. Canonical correspondence analysis (CCA) of the relationship between the floristic composition of the vegetation plots (relevés) and the spatial distribution of insect visitors and between the insect visitor pattern and Lamiaceae species traits. Grey points correspond to the dry grassland, black points to the railway embankment. Eigenvalues: Axis $1-0.41$, Axis $2-0.38$. The diagram explains $66.4 \%$ of total variance. Explanations: species richness (Richness), species diversity (Diversity), the 'blossom cover' i.e. flower abundance (Cover), flowering season (Flowering), amount of pollen (Pollen A), energy available in pollen (Pollen E), and protein content in pollen (Pollen P).

Tab. 5. Simple effects and conditional effects obtained from the summarize effects of explored variables in CCA model. Explanations: species richness (Richness), species diversity (Diversity), flower abundance (Cover), flowering season (Flowering), amount of pollen (Pollen A), energy available in pollen (Pollen E), protein content in pollen (Pollen $\mathrm{P}$ ), ${ }^{\star} \mathrm{P}<0.05$, ns - non significant.

\begin{tabular}{lcc}
\hline Variable & $\begin{array}{c}\text { Simple } \\
\text { effects }\end{array}$ & $\begin{array}{c}\text { Conditional } \\
\text { effects }\end{array}$ \\
\hline Bumblebees & $16.6^{*}$ & $16.6^{*}$ \\
Pollen E $\left(\mathrm{kcal} \mathrm{m}^{-2}\right)$ & $16.5^{*}$ & $12.5^{*}$ \\
Honeybees & $15.5^{*}$ & $8.6^{\mathrm{ns}}$ \\
Pollen A $\left(\mathrm{g} \mathrm{m}^{-2}\right)$ & $14.4^{*}$ & $7.6^{\mathrm{ns}}$ \\
Solitary bees & $12.4^{*}$ & $7.4^{\mathrm{ns}}$ \\
Cover $(\%)$ & $12.3^{*}$ & $10.6^{*}$ \\
Flowering & $10.2^{*}$ & $10.2^{*}$ \\
Richness & $10.4^{*}$ & $10.1^{*}$ \\
Butterflies & $9.2^{\mathrm{ns}}$ & $8.0^{\mathrm{ns}}$ \\
Diversity & $8.4^{\mathrm{ns}}$ & $6.9^{\mathrm{ns}}$ \\
Beetles & $7.9^{\mathrm{ns}}$ & $5.0^{\mathrm{ns}}$ \\
Pollen $(\%)$ & $6.0^{\mathrm{ns}}$ & $4.5^{\mathrm{ns}}$ \\
Flies & $4.0^{\mathrm{ns}}$ & $3.2^{\mathrm{ns}}$ \\
\hline
\end{tabular}

the exception of butterflies, beetles and flies. In total, 2214 insect individuals were found during our survey (dry grassland vs. railway embankment -629 vs. 1585). The participation of flower visitors differed among the species; however, the main visitors to the Lamiaceae species were bees, with a predominance of honeybees (Fig. 3). Bumblebees were observed most abundantly in O. vulgare flowers (mean $=28 \%$ ) 


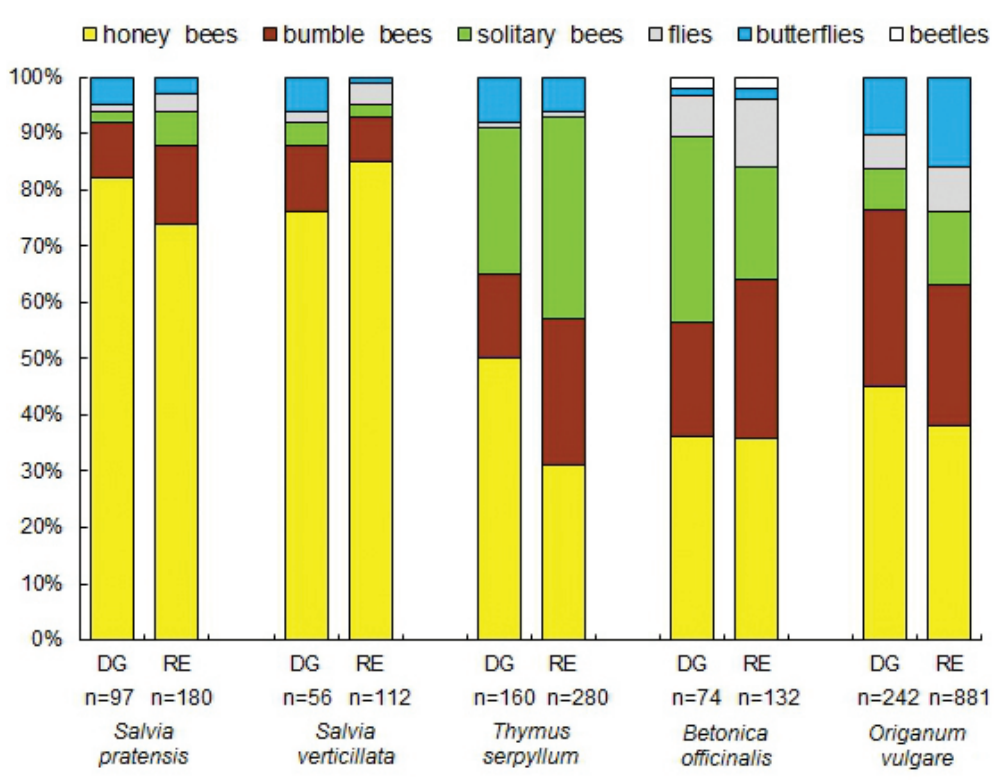

Fig. 3. Percentage participation of insect visitors on Lamiaceae species studied in dry grassland (DG) and railway embankment (RE). Mean values from the years 2013-2014 are given, $\mathrm{n}=$ total number of insect individuals recorded during observations.

and solitary bees in B. officinalis ( mean $=25.5 \%$ ). Flies were found in the flowers of all the studied species, but accounted for only $1.5 \%$ to $13.0 \%$ of visits, on average. Beetles were observed (mean $=2.1 \%$ ) only in the flowers of B. officinalis. For all the studied species, the general pattern of insect groups observed in the Lamiaceae flowers was quite similar between the habitats. However, the frequency of insect visitors to the flowers of the same Lamiaceae species differed significantly between the habitats and was higher on the railway embankments (approx. 4-fold) (Tab. 1). The relationship between the number of flowers and the frequency of insect visitors was not significant $(r=-0.271, P=0.488)$. During sunny weather, insect visitors collected nectar (approximately between 9.00-16.00) and pollen (approximately between 11.0015.00). This pattern was similar for all the species studied.

\section{Discussion}

Our study is a step towards quantifying the floral resources for pollinators. We found differences in flora attributes (plant species composition, species richness, species diversity, blossom cover, flowering spectrum) as well as the pollen mass and pollen energy available between the dry grassland and railway embankment biotopes. These disparities were intimately linked with the relative abundance and frequency of pollinators to the Lamiaceae species.

In our study, the blossom cover (= flower abundance) within vegetation patches significantly determined the insect visitor pattern to the Lamiaceae species, explaining $12.3 \%$ of the variance. It is accepted that abundantly flowering vegetation patches have a strong community-level influence on the activity of insect visitors to particular plant species (Kevan 1999). Similarly, Potts et al. (2003) documented the fact that greater numbers of individual insect foragers were simply recruited to plant species in floral community patches when floral resource availability progressively increased. Insects are sensitive to energy stress; therefore, energy intake plays an important role in their foraging modes. There is a positive correlation between the blossom cover and daily energy availability; therefore, flower-dense patches that offer higher energy reward are simply preferred to minimize the costs of search (e.g. Heinrich and Raven 1972, Heinrich 1975, Roberts and Harrison 1998, Waddington 2001, Cnaani et al. 2006).

In our study, both the pollen abundance and the pollen energy content significantly influenced the pattern of insect visitors to the Lamiaceae species (30.9\% of the variance). Pollen abundance determines the structure of bee fauna in the landscape of Mediterranean ecosystems (Potts et al. 2003). Also, the pollen energy content can considerably influence pollinator abundance (Petanidou and Vokou 1990). In general, pollen abundance is positively correlated with the amount of pollen produced per flower and the number of flowers produced per unit area. Lamiaceae species usually form dense patches and bloom abundantly, irrespective of the habitat and climatic zone (Petanidou and Vokou 1990, Denisow and Bożek 2008, Bożek 2008, Denisow 2011) and the quantity of floral reward offered in Lamiaceae species is undoubtedly of particular importance for the foraging economics of pollinators.

The protein content in pollen was not important for determination of the activity of insect visitors to the Lamiaceae species. Inconsistent results have sometimes been obtained concerning insect preferences to the protein content in pollen. Roulston et al. (2000) found that protein content in pollen did not affect foraging preferences of pollinators. 
By contrast, Hanley et al. (2008) noted that the protein content could be a selective factor in the choice of plant species foraged by the honeybee, since the pollen collectors clearly gathered larger amounts of pollen rich in protein. Possibly, the variation in the protein content (mean from 20.2-27.4\%) recorded for the Lamiaceae representatives in our study was too small to be noticed by the entomofauna. However, it is still not clear which pollen property is particularly important to insect visitors. Pollen is an almost exclusive source of the protein and non-carbon elements critical for the nourishment of larvae and development of adults (Keller et al. 2005, Müller et al. 2006, Nicolson 2011). As suggested by Lunau (2000), Castellanos et al. (2006), or Hanley et al. (2008), the scent released from the surface of pollen grains is more important than quality-driven pollen properties in determining insect food choice. According to Baker and Baker (1990), both protein content and the carbohydrate:lipid ratio influence the plant pollinator relationship and floral choices. Although the protein content in the pollen (on average more than 20\%) was not important for the activity of insect visitors to the Lamiaceae species, it was considered high (Roulston et al. 2000, Denisow 2011). According to different authors (e.g. Genissel et al. 2002, Vanderplanck et al. 2014), high protein content in pollen is attractive to pollen-collecting insects and positively correlates with the development of bee larvae (Roulston et al. 2000, Vaudo et al. 2015). Therefore, our view is that Lamiaceae species should be considered while suitable plant species to restore and/or develop a pasture for pollinators are being chosen.

We observed significant recruitment of honeybees, bumblebees, and solitary bees to the Lamiaceae species in our study patches. The preference of social bees (Apis mellifera, Bombus spp.) for Lamiaceae species has been evidenced by many authors in Mediterranean ecosystems (e.g. Petanidou and Vokou 1990, Petanidou et al. 2000). Different species from the Lamiaceae family have been classified as honeybee, bumblebee, or solitary bee species in Poland (Bożek 2000, 2003ab, Denisow and Bożek 2008, Denisow 2011). In contrast, butterflies, flies and beetles did not respond to the traits of Lamiaceae species. Flies and beetles show high preferences for whitish or yellow flowers with open, i.e. dish-, or bowlshaped, corollas (Glover 2014). These features do not fit our Lamiaceae species, which developed deep, pink, purple, or violet corollas. It is generally accepted that flower morphology (e.g. corolla deepness, flower size) and features of floral reward (e.g. composition of nectar sugars, nectar concentration, scent released from the surface of pollen grains) exert an impact on the behaviour of insect visitors and the guild structure in plant species (Petanidou et al. 2000, Nicolson and Thornburg 2007, Denisow and Wrzesień 2015a). Contrary to our expectations, the Lamiaceae species occurring in the homogeneous patches situated in the railway embankments received more insect visitors than the individuals in the heterogeneous ones. Our findings conflict with results presented by e.g. Fussell and Corbet 1992, Corbet 2000, Ebeling et al. 2008 or Wrzesień et al. 2016, who reported the highest frequency of pollinators for species occurring in high species-rich patches. A variety of factors affect insect visitor abundance and their frequency. At the community level, the size of the floral display (abundance of blooming), the flower attractiveness (i.e. flower morphology and traits of floral reward; discussed above), the co-flowering components of phytocoenoses, and the insect interactions with other individuals might be important in determining the flower choice by pollinators and their abundance and visitation frequency (Kunin 1997, Steffan-Dewenter 2003, Lázaro et al. 2009). Moreover, the insect population size and the number of nests in the immediate neighbourhood strongly shape the abundance and rates of insect visitors (Goulson 1999) and might be expected to have a dominant influence on the variation in the relative abundance of insect visitors to Lamiaceae flowers. At the level of individuals, the floral visitation frequency decreases linearly with the total number of flowers (see, e.g., Fussell and Corbet 1992, Steffan-Dewenter 2003). No relation between the number of flowers and insect visitor frequency was established in our study. The above reasons indicate that the recruitment of insect visitors to particular species in floral patches is likely to be a complex phenomenon. As revealed by Moron et al. (2014), due to the occurrence of bare ground, railway embankments constitute a particularly valuable habitat for diverse ground-nesting bees and wasps and support populations of butterflies and hoverflies. Presumably, the higher insect species richness and/or abundance in the railway biotope influence their number in our study species. However, a limitation of our study is that it does not include measurements of the insect diversity and population size between the habitats.

For the same species, pollen productivity differed in the spatio-temporal pattern. First, the space-varying growth conditions (e.g. nutrients and/or water availability) between the dry grassland and the railway embankment are presumably responsible for the diversity of inter-habitat pollen resources noted in our study. The habitat type has been documented to affect the pollen resource levels in flowers; hence, optimal habitat and /or environmental conditions are necessary to ensure efficient pollen resources (e.g. Denisow and Wrzesień 2015a, Denisow 2009, 2011). Second, significant differences in the amount of pollen produced in flowers between years are supportive of a strict relationship between changeable external environmental factors (weather conditions) and the mass of produced pollen. The considerable impact of the weather parameters during the differentiation of generative buds or microsporogenesis on the mass of pollen was emphasized in many studies (e.g. Bożek 2003b, Aguilera and Valenzuela 2013). In extremely unfavourable weather conditions (e.g. temperature drops or prolonged shortage of precipitation), plants even fail to produce pollen (Denisow 2011). The year-to-year fluctuations in the total pollen yield and pollen energy available per unit area obtained from particular Lamiaceae species are understandable; they result from different factors that can occur at the same time, e.g. flora dynamics, disparity in pollen output per flower, and varying abundance of flowering in the patches of plant communities. Their effects on the variations in food 
resources (mass and energy) in plant communities was also described by Parrish and Bazzaz (1979), Tanacs and Gulyas (1986), Petanidou and Vokou (1990), Petanidou and Smets (1995), or Denisow (2011).

Our data provide strong evidence that insect abundance in Lamiaceae species vary with flowering phenology $(10.2 \%$ of variance). We have demonstrated community-level differences in the seasonal blooming spectrum between the dry grassland and the railway embankment. Abundant flowering begins earlier in the season in the dry grassland habitat, while railway embankment flora ensures resource availability at the end of the season. Abundant spring flowering and a decrease during the summer-drought period is a distinct feature of the flora in dry grassland communities in Europe and relate to the predominance of perennial life forms (Klimešová et al. 2008). A scarcity of plants flowering in spring and a shift in flowering abundance towards the end of the season was highlighted for alternative man-made habitats (Denisow 2011, Denisow and Wrzesień 2015b, Wrzesień et al. 2016). Therefore, to provide pollinators with a balanced diet throughout the vegetation season, diverse habitats (semi-natural and man-made) are required in the landscape to supply a complementary bloom pattern and ensure continuity of food resources. High values of landscape heterogeneity have been proposed to increase the pollinator biodiversity ( $\beta$-diversity hypothesis; Steffan-Dewenter et al. 2002, Tscharntke et al. 2012).

\section{References}

Aguilera, F., Valenzuela, L. R., 2013: Time trend in the viability of pollen grains in the 'Picual' olive (Olea europaea L.) cultivar. Palynology 37, 28-34.

Alaux, C., Ducloz, F., Crauser, D., Le Conte, Y., 2010: Diet effects on honeybee immunocompetence. Biology Letters 6, 562-565.

Albrecht, M., Duelli, P., Schmid, B., Müller, C. B., 2007: Interaction diversity within quantified insect food webs in restored and adjacent intensively managed meadows. Journal of Animal Ecology 76, 1015-1025.

Baker, H. G., Baker, I., 1990: The predictive value of nectar chemistry to the recognition of pollinator types. Israel Journal of Botany 39, 157-166.

Banaszak-Cibicka, W., Żmihorski, M., 2012: Wild bees along an urban gradient: winners and losers. Journal of Insect Conservation $16,331-343$.

Bożek, M., 2000: Flower-pollinating insects of 32 species from Lamiaceae family. Pszczelnicze Zeszyty Naukowe 44, 293-303.

Bożek, M., 2003a: Foraging activity of Apis mellifera in the species from Lamiaceae family. Annales UMCS, sec EEE 12, 6774 (in Polish).

Bożek, M., 2003b: Pollen efficiency and foraging by insect pollinators in three catnip (Nepeta L.) species. Journal of Apicultural Science 47, 19-24.

Bożek, M., 2008: Pollen yield and pollen grain dimensions of some late-summer plant species of the Lamiaceae family. Journal of Apicultural Science 52, 31-35.

Braun-Blanquet J., 1964: Pflanzensociologie. Grundzüge der Vegetationskunde. 3. Auflage Springer-Verlag, Wien.
In conclusion, due to their abundant blooming, the amount of pollen resources provided, the pollen caloric value, and the high protein content in the pollen, Lamiaceae species attract a variety of insect pollinators. Therefore, Lamiaceae species should be considered in the protocol to improve food resources for pollinators to guarantee constant and high quality of food resources. However, the substantial inter- and intra-species disparities in pollen quality should not be ignored, especially if we intend to provide sufficient floral resources for pollinators on a landscape scale (Winfree 2010, Nicolson 2011).

\section{Acknowledgements}

The material from the species growing within the protected xerothermic grassland areas was collected in compliances with Polish law under permit from the Regional Nature Conservator in Lublin. Our thanks go also to Michał Wrzesień, who supported the logistics. We are grateful to Mrs Anna Wesołowska-Zoń for improving our English. Research was supported financially by the Ministry of Science and Higher Education of Poland as a part of the statutory activities of Department of Botany (project OKB/DS/2), University of Life Sciences in Lublin and Department of Geobotany, Institute of Biology and Biochemistry, Maria Curie-Skłodowska University in Lublin.

Castellanos, M. C., Wilson, P., Keller, S. J., Wolfe, A. D., Thomson, J. D., 2006: Anther evolution: pollen presentation strategies when pollinators differ. The American Naturalist 167, 288-296.

Cnaani, J., Thomson, J. D., Papaj, D. R., 2006: Flower choice and learning in foraging bumblebees: effects of variation in nectar volume and concentration. Ethology 112, 278-285.

Corbet, S. A., 2000: Conserving compartments in pollination webs. Conservation biology 14, 1229-1231.

Denisow B., 2011: Pollen production of selected ruderal plant species in the Lublin area. University of Life Sciences Press, Lublin.

Denisow, B, Bożek, M., 2008: Blooming and pollen production of two Lamium L. species. Journal of Apicultural Science 52, 21-30.

Denisow, B., 2009: Pollen production, flowering and insects visits on Euphorbia cyparissias L. and Euphorbia virgultosa Klok. Journal of Apicultural Research 48, 50-59.

Denisow, B., Wrzesień M., 2007: The anthropogenic refuge areas for bee flora in agricultural landscape. Acta Agrobotanica, 60, 147-157.

Denisow, B., Wrzesień M., 2015a: The habitat effect on the diversity of pollen resources in several Campanula spp. - an implication for pollinator conservation. Journal of Apicultural Research 54, 62-71.

Denisow, B., Wrzesień, M., 2015b: The importance of field-margin location for maintenance of food niches for pollinators. Journal of Apicultural Science 59, 27-37. 
Dicks L.V., Baude M., Roberts S. M., Phillips J, Green M., Carvell C., 2015: How much flower-rich habitat is enough for wild pollinators? Answering a key policy question with incomplete knowledge. Ecological Entomology 40, 22-35.

Ebeling, A., Klein, A. M., Schumacher, J., Weisser, W. W., Tscharntke, T., 2008: How does plant richness affect pollinator richness and temporal stability of flower visits? Oikos 117, 18081815.

Fussell, M., Corbet, S. A., 1992: Flower usage by bumble-bees: a basis for forage plant management. Journal of Applied Ecology 29, 451-465.

Gallai, N., Salles, J. M., Settele, J., Vaissière, B. E., 2009: Economic valuation of the vulnerability of world agriculture confronted with pollinator decline. Ecological Economics 68, 810-821.

Garbuzov, M., Ratnieks, F.L.W., 2014: Quantifying variation among garden plants in attractiveness to bees and other flower-visiting insects. Functional Ecology 28, 364-374.

Garibaldi, L. A., Steffan-Dewenter, I., Winfree, R., Aizen, M. A., Bomarco, R. Cunningham, S., Kremen, C., Carvalheiro,L. G., Harder, L. D., Afik,O., Bartomeus, I., Benjamin, F., Boreux, V., Daniel Cariveau, D., Chacoff, N. P., Dudenhöffer, J. H., Freitas, B. M., Ghazoul, J., Greenleaf, S., Hipólito, J., Andrea Holzschuh, A., Howlett,B., Isaacs, R., Javorek, S. K., Kennedy, Ch. M., Krewenka, K. M., Krishnan, S., Mandelik, Y., Mayfield, M. M., Motzke, I., Munyuli, T., Nault, B. A., Otieno, M., Petersen, J., Pisanty, G., Potts, S. G., Rader, R., Ricketts, T. H., Rundlöf, M., Seymour, C. L., Schüepp, Ch., Szentgyörgyi, H., Taki, H., Tscharntke, T., Vergara, C. H., Viana, B. F., Wanger, T. C., Westphal, C., Williams, N., Klein, A. M., 2013: Wild pollinators enhance fruit set of crops regardless of honey bee abundance. Science 339, 1608-1611.

Génissel, A., Aupinel, P., Bressac, C., Tasei, J. N., Chevrier, C., 2002: Influence of pollen origin on performance of Bombus terrestris micro-colonies. Entomologia Experimentalis et Applicata $104,329-336$

Ghazoul, J., 2005: Buzziness as usual? Questioning the global pollination crisis. Trends in Ecology and Evolution 20, 367-373.

Glover, B., 2014: Understanding flowers and flowering. Oxford University Press, Oxford.

González-Varo, J. P., Biesmeijer, J. C., Bommarco, R., Potts, S. G., Schweiger, O., Smith H. G., Vila, M., 2013: Combined effects of global change pressures on animal-mediated pollination. Trends in Ecology Evolution 28, 524-530.

Goulson, D., 1999: Foraging strategies of insects for gathering nectar and pollen, and implications for plant ecology and evolution. Perspectives in Plant Ecology, Evolution and Systematics 2, 185-209.

Hanley, M. E., Franco, M., Pichon, S., Darvill, B. Goulson, D., 2008: Breeding system, pollinator choice and variation in pollen quality in British herbaceous plants. Functional Ecology 22, 592-598.

Heinrich, B., 1975: Energetics of pollination. Annual Review Ecology and Systematics 6, 139-170.

Heinrich, B., Raven, P. H., 1972: Energetics and pollination ecology. Science 176, 597-602.

Hoekstra, J. M., Boucher, T. M., Ricketts, T. H., Roberts, C., 2005: Confronting a biome crisis: Global disparities of habitat loss and protection. Ecology Letters 8, 23-29.

Hülsmann, M., von Wehrden, H., Klein, A.-M., Leonhardt, S. D., 2015: Plant diversity and composition compensate for negative effects of urbanization on foraging bumble bees. Apidologie 46, 760-770.

Kaszewski, B. M., 2008: Climatic conditions of the Lubelskie Region. Maria Curie-Skłodowska University Press, Lublin (in Polish).

Keller, I., Fluri, P., Imdorf, A., 2005: Pollen nutrition and colony development in honey bees. Bee World 86, 27-34.
Kevan, P. G., 1999: Pollinators as bioindicators of the state of the environment: species, activity and diversity. Agriculture, Ecosystems and Environment 74, 373-393.

Klein, A. M., Vaissiere, B. E., Cane, J. H., Steffan-Dewenter, I., Cunningham, S. A., Kremen, C., Tscharntke, T., 2007: Importance of pollinators in changing landscapes for world crops. Proceedings of the Royal Society of London B: Biological Sciences 274, 303-313.

Klimešová J., Latzel V., de Bello F., van Groenendael J. M., 2008: Plant functional traits in studies of vegetation changes in response to grazing and mowing: towards a use of more specific traits. Preslia 80, 245-253.

Kovach, W. L., 2005: MVSP - A MultiVariate Statistical Package for Windows, ver. 3.1. Kovach Computing Services, Pentraeth, Wales, UK.

Kunin, W. E., 1997: Population size and density effects in pollination: pollinator foraging and plant reproductive success in experimental arrays of Brassica kaber. Journal of Ecology $85,225-234$.

Lázaro, A., Jakobsson, A., Totland, Ø., 2013: How do pollinator visitation rate and seed set relate to species' floral traits and community context?. Oecologia 173, 881-893.

Lázaro, A., Lundgren, R., Totland, Ø., 2009: Co-flowering neighbors influence the diversity and identity of pollinator groups visiting plant species. Oikos 118, 691-702.

Lonsdorf, E., Kremen, C., Ricketts, T., Winfree, R., Williams, N., Greenleaf, S., 2009: Modelling pollination services across agricultural landscapes. Annals of Botany 103, 1589-1600.

Lowenstein, D. M., Matteson, K. C., Minor, E. S., 2015: Diversity of wild bees supports pollination services in an urbanized landscape. Oecologia 179, 811-821.

Lunau, K., 2000: The ecology and evolution of visual pollen signals. In: Dafni, A., Hesse, M., Pacini, E. (eds.), Pollen and pollination, 89-111. Springer, Vienna.

Mirek, Z., Piękoś-Mirkowa, H., Zając, A., Zając, M., 2002: Flowering plants and pteridophytes of Poland. A checklist. Kraków: W. Szafer Institute of Botany, Polish Academy of Science.

Moroń, D., Skórka, P., Lenda, M., Rożej-Pabijan, E., Wantuch, M., Kajzer-Bonk, .... Tryjanowski, P., 2014: Railway embankments as new habitat for pollinators in an agricultural landscape. PLoS ONE 9, e101297.

Müller, A., Diener, S., Schnyder, S., Stutz, K., Sedivy, C., Dorn, S., 2006: Quantitative pollen requirements of solitary bees: implications for bee conservation and the evolution of bee-flower relationships. Biological Conservation 130, 604-615.

Nicolson, S. W., 2011: Bee food; the chemistry and nutritional value of nectar, pollen and mixtures of the two. African $\mathrm{Zo}$ ology 46, 197-204.

Nicolson, S.W., Thornburg, R. W., 2007: Nectar chemistry. In: Nicolson, S. W., Nepi, M., Pacini, E. (eds.), Nectaries and nectar, 215-263. Springer, Dordrecht.

Ollerton, J., Erenler, H., Edwards, M., Crockett, R., 2014: Extinctions of aculeate pollinators in Britain and the role of largescale agricultural changes. Science 346, 1360-1362.

Pacini, E., 2000: From anther and pollen ripening to pollen presentation. Plant Systematics and Evolution 222, 19-43.

Parrish, J. A. D., Bazzaz, F. A., 1979: Difference in pollination niche relationships in early and late successional plant communities. Ecology 60, 597-610.

Petanidou, T., Goethals, V., Smets, E., 2000: Nectary structure of Labiatae in relation to their nectar secretion and characteristics in a Mediterranean shrub community: does flowering time matter? Plant Systematics and Evolution 225, 103-118.

Petanidou, T., Smets, E., 1995: The potential of marginal lands for apiculture nectar secretion in Mediterranean shrublands. Apidologie 26, 39-52. 
Petanidou, T., Vokou, D., 1990: Pollination and pollen energetics in Mediterranean ecosystems. American Journal of Botany 39, 133-141.

Potts, S. G., Vulliamy, B., Dafni, A., Ne'eman, G., O'Toole, C., Roberts, S., Willmer, P., 2003: Response of plant-pollinator communities following fire: changes in diversity, abundance and reward structure. Oikos 101, 103-112.

Rabie, A. L., Wells, J. D., Dent, L.K., 1983: The nitrogen content of pollen protein. Journal of Apicultural Research 22, 119-123.

Roberts, S. P., Harrison, J. F., 1998: Mechanisms of thermoregulation in flying bees. American Zoologist 38, 492-502.

Roulston, T. H., Cane, J. H., 2000: Pollen nutritional content and digestibility for animals. Plant Systematics and Evolution 222, 187-209.

Roulston, T. H., Cane, J. H., Buchmann, S. L., 2000: What governs protein content of pollen: pollinator preferences, pollenpistil interactions, or phylogeny? Ecological Monographs 70, 617-643.

Roulston, T. H., Goodell, K., 2011: The role of resources and risks in regulating wild bee populations. Annual Review of Entomology 56, 293-312.

Stanisz, A., 2007: Accessible course in statistics Rusing Statistica Software on ex ample from medicine. Statsoft Polska, Kraków.

Steffan-Dewenter, I., 2003: Importance of habitat area and landscape context for species richness of bees and wasps in fragmented orchard meadows. Conservation Biology 17, 10361044.

Steffan-Dewenter, I., Münzenberg, U., Bürger, C., Thies, C., Tscharntke, T., 2002: Scale-dependent effects of landscape context on three pollinator guilds. Ecology 83, 1421-1432.

Szczęsna, T., 2006: Protein content and amino acid composition of bee-collected pollen from selected botanical origins. Journal of Apicultural Science 50, 81-90.

Szigeti, V., Kőrösi, Á., Harnos, A., Nagy, J., Kis, J., 2016: Measuring floral resource availability for insect pollinators in temperate grasslands-a review. Ecological Entomology 41, 231-240.

Tanacs, L., Gulyas, S., 1986: The role of the food area and slopes of dam of the river Tisza in feeding wild bees. Acta Biologica Szegediensis 32, 103-120.

Ter Braak, C. J. F., Šmilauer, P., 2012: Canoco reference manual and user's guide: software for ordination, version 5.0. Microcomputer Power, Ithaca, USA.
Tscharntke, T., Clough, Y., Wanger, T. C., Jackson, L., Motzke, I., Perfecto, I., Whitbread, A., 2012: Global food security, biodiversity conservation and the future of agricultural intensification. Biological Conservation 151, 53-59.

Vanbergen, A. J., 2013: Threats to an ecosystem service: pressures on pollinators. Frontiers in Ecology and the Environment 11, 251-259.

Van der Maarel, E., 1979: Transformation of cover-abundance values in phytosociology and its effect on community similarity. Vegetatio 39, 97-114.

Vanderplanck, M., Moerman, R., Rasmont, P., Lognay, G., Wathelet, B., Wattiez, R., Michez, D., 2014: How does pollen chemistry impact development and feeding behaviour of polylectic bees? PLoS One 9:e86209

Vaudo, A. D., Tooker, J. F., Grozinger, C. M., Patch, H. M., 2015: Bee nutrition and floral resource restoration. Current Opinion in Insect Science 10, 133-141.

Verboven, H. A., Uyttenbroeck, R., Brys, R., \& Hermy, M., 2014: Different responses of bees and hoverflies to land use in an urban-rural gradient show the importance of the nature of the rural land use. Landscape and Urban Planning 126, 31-41.

Waddington, K. D., 2001: Subjective evaluation and choice behavior by nectar-and pollen-collecting bees. In: Chittka, L., Thomson, J. D. (eds.), Cognitive ecology of pollination, 41-60. Cambridge University Press, Cambridge.

WallisDeVries, M. F., Poschlod, P., Willems, J. H., 2002: Challenges for the conservation of calcareous grasslands in northwestern Europe: integrating the requirements of flora and fauna. Biological Conservation 104, 265-273.

Winfree, R., 2010: The conservation and restoration of wild bees. Annals of the New York Academy of Sciences 1195, 169-97.

Wrzesień, M., Denisow B., 2006a: The share of nectariferous and polleniferous taxons in chosen patches of thermophilous grasslands of the Lublin Upland. Acta Agrobotanica 59, 213 221.

Wrzesień M., Denisow B., 2006b. The usable taxons in spontaneous flora of railway areas of the central-eastern part of Poland. Acta Agrobotanica 59, 95-108.

Wrzesień, M., Jachuła, J., Denisow, B., 2016: Railway embankments - refuge areas for food flora, and pollinators in agricultural landscape. Journal of Apicultural Science 60, 39-51. 